Jurnal DIALOGIKA Manajemen dan Administrasi

Homepage: https://ejournal.unma.ac.id/index.php/dialogika

Vol. 2, No. 1 Oktober 2020 halaman: $47 \sim 61$

E-ISSN: 2720-9865, P-ISSN: 2716-3563

DOI: https://doi.org/10.31949/dialogika.v2i1.2176

\title{
PENGARUH KOMPETENSI MANAJERIAL DAN SUPERVISI KEPALA SEKOLAH TERHADAP PENINGKATAN KINERJA GURU
}

\author{
${ }^{1}$ Lelah, ${ }^{2}$ Djam'an Satori, ${ }^{3}$ Kania Agustina \\ (1)Mahasiswa Magister Ilmu Administrasi, Universitas Majalengka, Jawa Barat, Indonesia \\ (2)(3)Dosen Magister Ilmu Administrasi, Pascasarjana Universitas Majalengka, Jawa Barat, Indonesia \\ e-mail korespondensi :lelah.76@gmail.com
}

Disubmit Agustus 2020 , Diterima September 2020 , Diterbitkan Oktober 2020

Submitted August 2020 , Accepted September 2020 , Published October 2020

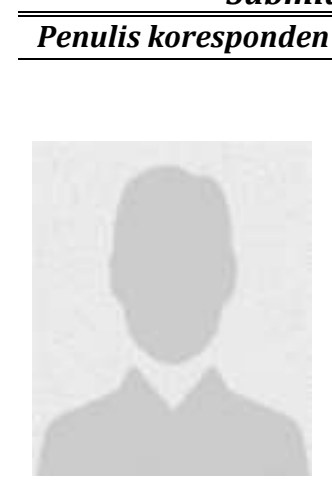

Abstract

The purpose of this study was to analyze the effect of managerial competence and supervision on teacher performance. In this study, the research method used by the author in this study is an empirical study method, namely research on empirical facts obtained based on observation and experience. The sample in this study were all teachers at three SMPN Banjaran with the technique of taking it by census, that is, the entire population was used as the research sample. The analysis technique used in this research is correlational. Managerial competence based on the results of hypothesis testing statistically shows a positive and significant effect on teacher performance. Principal supervision activities based on the results of statistical hypothesis testing showed a positive and significant effect on teacher performance. Managerial competence and supervision of principals based on the results of statistical hypothesis testing simultaneously show a positive and significant effect on teacher performance.

Jurnal DIALOGIKA
Manajemen dan
Administrasi
diterbitkan oleh
Program Studi
Administrasi Publik
Pascasarjana
Universitas
Majalengka

Keywords: Managerial Competence, Supervision and Teacher Performance

\begin{tabular}{l}
\hline Abstrak \\
Tujuan penelitian ini untuk menganalisis pengaruh kompetensi manajerial dan \\
supervisi terhadap kinerja guru. Dalam penelitian ini metode penelitian yang \\
digunakan penulis dalam penelitian ini adalah metode studi empiris, yaitu penelitian \\
terhadap fakta empiris yang diperoleh berdasarkan observasi dan pengalaman. \\
Sampel dalam penelitian ini adalah semua guru di tiga SMPN Banjaran dengan teknik \\
pengambilannya dilakukan secara sensus, yaitu seluruh populasi dijadikan sampel \\
penelitian. Teknik analisis yang digunakan pada penelitian ini adalah korelasional. \\
Kompetensi manajerial yang didasarkan dari hasil uji hipotesis secara statistic \\
menunjukkan berpengaruh positif dan signifikan terhadap kinerja guru. Kegiatan \\
supervisi kepala sekolah yang didasarkan dari hasil uji hipotesis secara statistic \\
menunjukkan berpengaruh positif dan signifikan terhadap kinerja guru. Kompetensi \\
manajerial dan supervisi kepala sekolah yang didasarkan dari hasil uji hipotesis secara \\
statistic secara simultan menunjukkan berpengaruh positif dan signifikan terhadap \\
kinerja guru.
\end{tabular}

Kata kunci: Kompetensi Manajerial, Supervisi dan Kinerja Guru.

(i) This work is licensed under a Creative Commons Attribution 4.0 International License

\section{PENDAHULUAN}

Pada perkembangan zaman dan tantangan kehidupan modern saat ini, pendidikan menjadi salah satu yang sangat penting disebabkan karena pendidikan merupakan salah satu penentu sumber daya manusia. Pendidikan yang berhasil yaitu pendidikan yang mampu menghasilkan sumber daya manusia yang berkualitas. Pendidikan yang dikelola secara profesional oleh tenaga pendidik yang profesional juga. Guru memiliki peranan yang penting dalam 
pendidikan sehingga guru harus memiliki kompetensi professional. Menurut Murip Yahya (2013:24) dalam Undang-Undang Guru dan Dosen Nomor 14 tahun 2005 dijelaskan bahwa: "yang dimaksud guru adalah pendidik profesional dengan tugas utama mendidik, mengajar, membimbing, mengarahkan, melatih, menilai dan mengevaluasi peserta didik pada pendidikan usia dini jalur pendidikan formal, pendidikan dasar dan menengah".

Pendidikan merupakan salah satu pilar terpenting dalam meningkatkan kualitas sumber daya manusia, dalam konteks itu guru memegang peranan penting dan tidak bisa diabaikan karenanya berbagai kebijakan pengembangan dan peningkatan mutu guru harus senantiasa dilakukan untuk meningkatkan kualitas kinerjanya. Dalam upaya menghasilkan sekolah yang berkualitas, banyak faktor yang terlibat di dalamnya, salah satu peranan yang sangat menentukan adalah kepala sekolah. Kedudukan kepala sekolah dalam penyelenggaraan pendidikan di sekolah merupakan figur sentral yang bertanggung jawab terhadap lancarr tidaknya kegiatan proses pendidikan di sekolah. Sumber daya manusia, keuangan, sarana dan prasarana serta informasi tidak akan dapat berperan optimal dalam pencapaian tujuan sekolah tanpa dikelola dengan baik oleh kepala sekolah.

Kepemimpinan hanya dapat dilaksanakan oleh seorang leader, dimana pemimpin adalah seorang yang mempunyai keahlian memimpin. Pemimpin di sekolah adalah kepala sekolah. Kepala sekolah haruslah memiliki kecakapan untuk dapat mempengaruhi tenaga pendidik dan kependidikan untuk bersama-sama melakukan kegiatan atau aktivitas demi mencapai tujuan. Sejalan dengan pemahaman Donni Juni Priansa dan Risma Somad (2014:49) Mengatakan bahwa: "pemimpin atau leadership yaitu kemampuan untuk menggerakkan sumber daya, baik internal maupun ekstenal dalam rangka mencapai tujuan sekolah dengan optimal". Sedangkan menurut Abd Wahab H.S dan Umiarso (2010:89) mendefenisikan kepemimpinan adalah "suatu kegiatan mempengaruhi orang lain agar orang tersebut mau bekerja sama (mengolaborasi dan mengelaborasi potensinya) untuk mencapai tujuan yang telah ditetapkan".

Kepemimpinan kepala sekolah merupakan salah satu faktor yang dapat mendorong sekolah untuk dapat mewujudkan visi, misi, tujuan dan sasaran sekolahnya melalui programprogram yang dilaksanakan secara terencana dan bertahap. Kepala sekolah dituntut mempunyai kemampuan manajemen dan kepemimpinan yang memadai agar mampu mengambil inisiatif dan prakarsa untuk meningkatkan mutu sekolah. Hal ini menunjukkan bahwa peran kepala sekolah sedemikian penting untuk menjadikan sebuah sekolah pada tingkatan yang efektif. Asumsinya adalah bahwa sekolah yang baik akan selalu memiliki kepala sekolah yang baik, artinya kemampuan profesional kepala sekolah dan kemauannya untuk bekerja keras dalam memberdayakan seluruh potensi sumber daya sekolah menjadi jaminan keberhasilan sebuah sekolah. Untuk lebih mengefektifkan pelaksanaan pekerjaannya dan dapat mendayagunakan seluruh potensi sumber daya yang ada di sekolah maka kepala sekolah harus memahami perannya.

Kepala Sekolah sebagai pendidik dan tenaga kependidikan mempunyai peran yang sangat besar dalam mendukung peningkatan kinerja pendidikan disekolah. Peran kepala sekolah dalam mengembangkan suasana sekolah yangnyaman dan kondusif bagi proses belajar mengajar melalui pengelolaan manajerial yang profesional merupakan kebutuhan utama suatu sekolah untuk meraih prestasi dalam rangka menghasilkan sumberdaya manusia unggul dan berdaya-saing. Keberhasilan kinerja akan tampak apabila terdapat motivasi kepala sekolah, lingkungan sekitar juga dapat menentukan keberhasilan kinerja seseorang oleh karena itu, selain gurunya sendiri yang berusaha meningkatkan kualitas kerjanya, pihak sekolah juga berusaha mengupayakan pemberdayaan gurunya agar memiliki kinerja yang baik, dan profesional dalam menjalankan tugasnya.

Menurut Wibowo mengatakan bahwa "Kinerja adalah tentang apa yang dikerjakan dan bagaimana cara mengerjakannya". Kinerja yang baik 
mencerminkan bahwa guru tersebut telah mampu memenuhi kewajiban dan tanggungjawabnya sebagai seorang yang profesional. Guru memiliki tugas utama bukan hanya mengajar akan tetapi mendidik peserta didiknya.

Dalam proses pembelajaran, peningkatan hasil belajar peserta didik pada lembaga pendidikan antara lain dilihat dari segi meningkatnya prestasi peserta didik tersebut dalam ujian, ini tentu dipengaruhi oleh keberhasilan kinerja guru dalam proses mengajar dan proses pembelajaran akan berlangsung dengan baik apabila didukung oleh guru yang mempunyai kompetensi dan kinerja yang tinggi, sebagaimana dijelaskan E Mulyasa (2013:103) bahwa: "kinerja guru dalam pembelajaran berkaitan dengan kemampuan guru dalam merencanakan, melaksanakan dan menilai pembelajaran, baik yang berkaitan dengan proses maupun hasilnya".

Begitu besarnya peranan kepala sekolah dalam proses pencapaian tujuan pendidikan. Demikian halnya dengan guru. Guru akan baik kinerjanya jika kepala sekolah senantiasa membina dan membimbingnya. Guru merupakan ujung tombak dalam sistem pendidikan secara keseluruhan. Guru selalu terkait dengan komponen manapun dalam pendidikan dan merupakan komponen paling berpengaruh terhadap terciptanya proses dan hasil pendidikan yang berkualitas. Oleh karena itu, upaya perbaikan apapun yang dilakukan untuk meningkatkan kualitas pendidikan tidak akan memberikan sumbangan yang signifikan tanpa di dukung oleh guru yang profesional dan berkualitas.

Kepala sekolah merupakan salah satu komponen pendidikan yang berpengaruh dalam meningkatkan kinerja guru. Kepala sekolah bertanggung jawab atas penyelenggaraan pendidikan, diantaranya: administrasi sekolah, pembinaan tenaga kependidikan lainnya, dan pendayagunaan serta pemeliharaan sarana dan prasarana. Menurut Sumadi (2012:6) akhir-akhir ini ada gejala kecenderungan melemahnya kinerja guru bahwa: Guru melaksanakan tugasnya hanya sekedarnya saja tanpa ada persiapan materi maupun metode pengajaran yang akan digunakan. Guru tidak menguasai materi dengan kuat sehingga pembelajaran menjadi monoton yang penting cepat selesai maka tentunya berpengaruh kepada siswanya.

Fenomena yang ditemukan penulis di 3 (tiga) Sekolah Menengah Pertama Negeri yaitu SMPN 1 Banjaran, SMPN 2 Banjaran dan SMPN 3 Banjaran Kecamatan Banjaran Kabupaten Majalengka, ternyata kompetensi manajerial dan kompetensi supervisi kepala sekolah di tiga sekolah itu belum optimal. Terbukti dan ditemukan bahwa sebagian besar kepala sekolah belum dibekali dan memahami standar kompetensi sebagai kepala sekolah terutama kompetensi manajerial dan supervisi, sehingga kemampuan mereka sangat minim dalam mengelola sekolah, rumusan tujuan sekolah kurang berorientasi pada visi, tata tertib sekolah sering dilanggar, program-program kepala sekolah jarang dilakukan sehingga memberikan berpengaruh terhadap kinerja guru dan berdampak terhadap hasil belajar siswa. Masalah yang muncul di tiga sekolah tersebut hampir sama sehingga mempengaruhi kinerja guru dalam proses pembelajaran. Fenomena tersebut yakni:

- Kompetensi Manajerial : kepala sekolah jarang mengontrol kehadiran guru di sekolah, kepala sekolah sering tidak hadir ke sekolah dengan alasan rapat dinas apalagi yang aktif di organisasi lain, kepala sekolah jarang menegur guru yang tidak mengikuti kegiatan sekolah.

- Kompetensi Supervisi : kepala sekolah jarang mengawasi aktifitas guru di sekolah sehingga banyak guru yang telat masuk terutama jam pelajaran pertama, banyak guru membuat RPP hanya di awal tahun ajaran, guru banyak dibebani tugas kelengkapan adaministrasi tapi tidak di evaluasi, beberapa guru belum dapat mengoperasikan perangkat pembelajaran yang berbasis IT.

Adanya permasalahan yang dialami seperti yang telah dipaparkan di atas, maka akan sulit untuk mencapai hasil yang diharapkan, yaitu pendidikan dan pembelajaran yang berkualitas tinggi. Oleh karena itu, perlu dilakukan penilaian terhadap kinerja guru menjadi bahan introspeksi bagi guru untuk memperbaiki 
kualitas pembelajarannya. Penilaian baik dan buruk kinerja seorang guru ditentukan oleh kompetensi manajerial dan supervisi seorang kepala sekolah. Menurut $\mathrm{H}$. Muhaimin (2010:412) bahwa pengukuran pencapaian sasaran kinerja kegiatan yang dilakukan kepala sekolah sebagai manajerial dan supervisor merupakan hasil penilaian yang sistematik yang didasarkan pada indikator kinerja yang telah ditetapkan.Pengukuran kinerja harus dilakukan melalui tahapan pengumpulan data, pengukuran dan penetapan tingkat kinerja.

Idealnya kepala sekolah telah merancang secara terjadwal dalam program keterlaksanaan dan ketercapaian kerja kepala sekolah sehingga tujuan akhir terwujud sesuai dengan visi dan misi sekolah. Kompetensi manajerial dan supervisi merupakan kompetensi yang saling berkaitan antara satu dengan yang lainnya. Ini dikarenakan kompetensi manajerial merupakan kompetensi kepala sekolah dalam merencanakan, mengorganisasikan, melaksanakan yang akhirnya mengawasi. Dalam perencanaan ini akan dilihat lagi kompetensi supervisi kepala sekolah. Hubungan antara kompetensi manajerial dan supervisi sangat mempengaruhi kinerja guru yang ada di lapangan. Hal ini disebabkan konsep perancangan yang memuat tentang keterlaksanaan dan ketercapaian guru dalam melaksanakan tupoksinya di dalam kelas telah dibuat berdasarkan penindaklanjutan supervisi sebelumnya.

Kepala sekolah dalam meningkatkan mutu pembelajaran, bertanggung jawab untuk memenuhi fungsi supervisi pengajarannya. Kepala sekolah sebagai supervisor dituntut agar mampu merencanakan program supervisi, melaksanakan serta menindak lanjutinya. Agar orang tersebut mau bekerja sama dengan baik atau tercipta suasana iklim yang kerja yang baik perlu adanya hubungan yang perlu dijaga. Seorang kepala sekolah perlu mengubah cara pandangnya terutama dalam pola hubungan atasan dan bawahan, yang ada dibenak kepala sekolah yang bersifat hirarkis-komando menuju ke sistem kemitraan. Menyadari hal ini, kepala sekolah hendaklah menitikberatkan pada kebersamaan antara tenaga pendidik dan kependidikan.

Berdasarkan hasil observasi tersebut, kepala sekolah sebagai tokoh utama di sekolah dituntut mampu bertindak sebagai manajer dan pemimpin yang efektif dalam mengelola segala aktivitas/kegiatan di sekolah agar semua sumber daya dapat berfungsi dan berjalansecara optimal. Kepala sekolah haruslah mampu sebagai perencana sekaliguspelaksana dan pengawas serta mampu menciptakan budaya dan iklim sekolah yangbaik. Dari fenomena di atas, penulis berpendapat bahwa kompetensi manajerial dan kompetensi supervisi kepala sekolah di tiga sekolah tersebut masih belum optimal dan belum seperti yang diharapkan. Oleh karena itu penulis tertarik untuk meneliti dan membahas permasalahan tentang kompetensi kepala sekolah dengan judul: "Pengaruhkompetensi manajerial dan supervisi kepala sekolah terhadap peningkatan kinerja guru SMPN di Kecamatan Banjaran Kabupaten Majalengka"

\section{TINJAUAN PUSTAKA}

Pengaruh kompetensi manajerial sebagai perancang sekaligus pelaksana serta pengawas berpengaruh pada kinerja guru. Kompetensi supervisi kepala sekolah sebagai perencana pelaksana sekaligus penindak lanjut berpengaruh terhadap kinerja guru.

1) Pengaruh Kompetensi Manajerial Kepala Sekolah Terhadap Kinerja Guru

Kemampuan manajerial merupakan kemampuan untuk menggerakkan orang lain dalam memanfaatkan sumber-sumber yang ada dalam mencapai tujuan organisasi secara efektif dan efisien. Ukuran seberapa efektif dan efisien seorang manajer adalah seberapa baik dia dapat menetapkan rencana dalam mencapai tujuan yang memadai, kemampuan memimpin secara efektif merupakan kunci keberhasilan organisasi.Kepala sekolah sebagai manajer pada pendidikan formal dituntut memiliki kemampuan manajemen dalam menjalankan tugas dan tanggung jawabnya agar mampu mencapai tujuan belajar mengajar secara keseluruhan. Seorang 
manajer haruslah mengerti kedudukannya dimana dia berada, dengan kata lain seorang pemimpin haruslah paham akan tanggung jawab yang ada pada dirinya. Wirawan berpendapat bahwa "pemimpin adalah tokoh atau elit anggota sistem sosial yang dikenal dan berupaya memengaruhi para pengikutnya secara langsung atau tidak langsung".(Wirawan, 2014:9). Menurut George Terry yang dikutip Ahmad Susanto (2016:2-3) mengatakan bahwa: Manajemen merupakan sebuah proses yang khas yang terdiri dari tindakatindakan yang meliputi: perencanaan (planning), pengorganisasian (organizing), gerakan (acting) dan pengawasan (controling), yang dilakukan untuk menentukan serta mencapai sasaran yang telah ditetapkan melalui pemanfaatan SDM serta sumber-sumber lainnya.

Kepala sekolah sebagai manajer harus mampu mengatur agar semua potensi sekolah dapat berfungsi secara optimal.Hal ini dapat dilakukan jika kepala sekolah mampu melakukan fungsi-fungsi manajemen dengan baik, meliputi perencanaan, pengorganisasian, pengarahan/pengendalian dan pengawasan. Kompetensi manajerial adalah kemampuan kepala sekolah dalammengorganisasi dan mengembangkan sumber daya sekolah untuk menciptakan lingkungan belajar yang efektif, efisien.Kepala sekolah dituntut untuk memiliki keterampilan dalam mengembangkan sumber daya manusia yang tersedia di sekolahnya, sehingga mereka benarbenar dapat diberdayakan dan memberikan kontribusi terhadap pencapaian tujuanpendidikan di sekolah. Menurut Karwati dan Priansa (2013: 119), "Kompetensi manajerial kepala sekolah dapat dilihat dari kemampuan kepala sekolah dalam menyusun perencanaan, pengembangan, pengelolaan dan pemberdayaan, secara optimal untuk mencapai tujuan sekolah". Kepala sekolah di tengah arus perubahan dalam rangka mewujudkan kehidupan sekolah yang sehat, kondusif, dan menunjang kerja setidaknya harus memiliki visi yang jelas tentang mutu, mengandalkan pendekatan kolaboratif dalam pembinaan sekolah, responsive dan proaktif, memiliki keteladanan, aktifdan turun kebawah, melakukan teknik ganjaran, pengembangan wahana yang mengarah pada pengembangan keterampilan pro sosial. Dikemukakan pula bahwa sebagai kepala administrasi, kepala sekolah bertugas untuk membangun manajemen sekolah serta bertanggung jawab dalam pelaksanaan keputusan manajemen dan kebijakan sekolah. Kepala sekolah dalam satuan pendidikan merupakan pemimpin. Kepala sekolah mempunyai dua jabatan dan peran penting dalam melaksanakan proses pendidikan. Pertama, kepala sekolah adalah pengelola pendidikan di sekolah dan kedua, kepala sekolah adalah pemimpin formal pendidikan di sekolahnya.

Kompetensi manajerial kepala sekolah dapat dilihat dari kemampuannya dalam penyusunan perencanaan sekolah untuk berbagai tingkat perencanaan; mengelola perubahan dan pengembangan sekolah menuju organisasi pembelajaran yang efektif, menciptakan budaya dan iklim sekolah yang kondusif dan inovatif bagi pembelajaran peserta didik dalam rangka penerimaan peserta didik baru; mengelolatenaga pendidik dan kependidikan, mengelola peserta didik dan pengembangan kurikulum dan kegiatan pembelajaran sesuai dengan arah dan tujuan pendidikan nasional, melakukan monitoring, evaluasi dan pelaporan pelaksanaan program kegiatan sekolah dengan prosedur yang tepat serta merencanakan tindak lanjutnya.

2) Pengaruh Kompetensi Supervisi Kepala Sekolah Terhadap Kinerja Guru

Supervisi menjadi landasan utama untuk menganalisis pelaksanaan kegiatan pengawasan profesional supervisi yang dimaksud adalah supervisi pembelajaran atau instruksional supervision.Dalam kajian ini yang dimaksud dengan supervisi profesional adalah sistem pemberian bantuan yang dilaksanakan oleh supervisor untuk meningkatkan kemampuan profesional guru, sehingga guru lebih mampu dalam menghadapi dan menangani tugas pokoknya dalam mendidik.

Mutu sebuah sekolah secara mendasar, berkaitan dengan supervisi kepala sekolah sebagai pemimpin terhadap tenaga pendidik yang ada di sekolah. Seorang 
kepala sekolah mempunyai hak dan kekuasaan yang besar dalam membuat satu kebijakan. Mengawasi dan melaksanakan agar sekolah yang dibinanya memiliki kemampuan untuk mengembangkan potensi yang ada. Kepala sekolah bertanggungjawab penuh dalam mengembangkan berbagai program sekolah, sebagai pengelola sekaligus mengawasinya. Kepala sekolah mempunyai keleluasaan dalam memanajemen segala sumber daya yang dimiliki sekolah, serta memanfaatkan secara besar-besaran untuk peningkatan mutu sekolah dan kinerja guru. Menurut Donni Juni Priansa \& Rismi Somad (2014:83) "Segala aktivitas pengarahan, bimbingan dan pengawasan yang dilakukan kepala sekolah kepada guru, staf dan pegawainya disebut dengan supervisi". Sedangkan menurut Sri Banun Muslim (2010:41) berpendapat bahwa "supervisi adalah serangkaian usaha pemberian bantuan kepada guru dalam bentuk layananprofesional yang diberikan oleh supervisor (kepala sekolah, penilik sekolah, dan pembina lainnya) guna meningkatkan mutu proses dan hasil belajar mengajar". Supervisor adalah seorang yang memperbaiki cara guru mengajar, cara belajar murid, peningkatan mutu serta penggunaan pelajaran.

Gurupun harus berusaha memperbaiki dan meningkatkan mutu kerjanya demi perkembangan jabatan dan kariernya serta tujuan sekolah. Kepala sekolah sebagai supervisor dituntut memiliki dua kapabilitas sekaligus yaitu, penguasaan model-model pembelajaran dan cara-cara memberikan bantuan kepada guru yang mengalami kesulitan dalam menerapkan model-model pembelajaran. Supervisi sangat penting dilakukan oleh seorang kepala sekolah sebagai salah satu upaya meningkatkan kinerja serta mengetahui kendala-kendala yang dihadapi guru didalam kelas (KBM) atau di luar kelas untuk mencapai visi dan misi pendidikan. Itulah sebabnya Budi Suhardiman (2012:48) mengatakan "Komponen atau yang harus dimiliki oleh seorang kepala sekolah yaitu 1) merencanakan program supervisi akademik; 2) melaksanakan supervisi dengan pendekatan dan tehnik yang tepat; dan 3) menindak lanjuti hasil supervisi akademik".
Jika supervisi dilakukan oleh kepala sekolah, maka haruslah kepala sekolah mampu melakukan pengawasan dan pengendalian untuk meningkatkan kinerja tenaga kependidikan. Pengawasan ini merupakan kontrol agar kegiatan pendidikan disekolah lebih terarah pada tujuan yang telah ditetapkan, pengawasan ini juga bertujuan sebagai tindakan untuk mencegah tenaga pendidik tidak melakukan penyimpangan dan lebih berhati-hati dalam melaksanakan tugasnya.

3) Pengaruh Kompetensi Manajerial dan Supervisi Kepala Sekolah Terhadap Kinerja Guru

Menurut Payaman (2008:12): Guru merupakan komponen paling menentukan dalam sistem pendidikan secara keseluruhan, yang harus mendapat perhatian central, pertama dan utama, figur yang satu ini akan senantiasa menjadi sorotan strategic ketika berbicara masalah pendidikan, karena guru selalu terkait dengan komponen manapun dalam system pendidikan, guru memegang peran utama dalam pembangunan pendidikan, khususnya yang diselenggarakan secara formal di sekolah, guru juga sangat menentukan keberhasilan peserta didik, terutama dalam kaitannya dengan proses belajar mengajar.

Guru benar-benar di tuntut untuk memiliki kinerja yang tinggi. Saeful (2008:34) "Dengan kinerja tinggi maka tingkat sumber daya manusia di Indonesia akan mulai sedikit demi sedikit meningkatkan terutama para generasi muda Indonesia. Sehingga terciptalah bangsa yang cerdas dan mampu menghadapi tantangan-tantangan masa depan" Kinerja guru dapat dinilaidari aspek kemampuan dasar yang harus dimiliki oleh seorang guru yang dikenal dengan sebutan "kompetensi guru". Kinerja guru merupakan seperangkat perilaku nyata yang ditunjukan pada saat menyampaikan pelajaran, dilihat ketika gur umelaksanakan tugas memfasilitasi proses pembelajaran termasuk mempersiapkan dan menilai prestasi belajar siswa. Menganalisa indikator kinerja guru yang berhubungan dengan pembelajaran maka secara sistematis kinerja guru dapat diketahui melalui kemampuan dan keterampilan dalam merencanakan program pengajaran, melaksanakan 
kegiatan pembelajaran dan mengevaluasi pembelajaran. Menurut Uzer Usman (2011:37) "ada beberapa upaya yang dapat dilakukan untuk meningkatkan kinerja guru, antara lain melalui pembinaan disiplin tenaga kependidikan, pemberian motivasi, penghargaan dan persepsi". Dalam upaya peningkatan mutu pendidikan di sekolah baik itu prestasi akademis dan non akademis, dibutuhkan kompetensi kepala sekolah yang sangat mumpuni. Dengan kompetensi tersebut apa yang dinginkan oleh masyarakat dan orangtua murid yakni tercapainya keberhasilan pendidikan di sekolah dapat terwujud, sehingga sekolah dengan apa yang dimiliki dapat berjalan dari berbagai bidang. Banyaknya kepala sekolah yang kurang memenuhi standar kompetensi ini tak terlepas dari proses rekrutmen dan pengangkatan kepala sekolah yang berlaku saat ini. Kepala sekolah selayaknya mampu memobilisasi atau memberdayakan semua potensi dan sumber daya yang dimiliki, terkait dengan berbagai program, proses, evaluasi, pengembangan kurikulum, pembelajaran di sekolah, pengolahan tenaga kependidikan, sarana prasarana, pelayanan terhadap siswa, hubungan dengan masyarakat, sampai pada penciptaan iklim sekolah yang kondusif. Semua ini akan terlaksana manakala kepala sekolah memiliki kompetensi untuk mempengaruhi semua pihak yang terlibat dalam kegiatan pendidikan disekolah, yaitu untuk bekerjasama dalam mewujudkan tujuan sekolah.

Penelitian ini menjelaskan pengaruh kompetensi manajerial dan supervisi kepala sekolah dalam meningkatkan kinerja guru, sesuai dengan Peraturan Menteri Pendidikan Nasional RI, Standar Kepala Sekolah/Madrasah, No 13 tahun 2007, sedangkan untuk penilaiaan kinerja guru berdasarkan pada Peraturan Menteri Pendidikan Nasional 16/2007 tentang Standar Kualifikasi Akademik dan Kompetensi Guru, BSNP versi 6.0. 11/2008 Kerangka untuk pelaporan Pencapaian Standar Nasional Pendidikan : Standar Kualifikasi Akademik dan Kompetensi Guru dan Permenegpan dan RB 16/2009 tentang Jabatan Fungsional Guru dan Angka Kreditnya.
Upaya perbaikan di bidang pendidikan hanya mungkin dicapai jika diawali dengan perbaikan manajemen pendidikan. Tidak ada lembaga sekolah yang baik kecuali dikelola secara baik. Bahkan dapat dikatakan, tidak ada lembaga sekolah yang buruk, yang ada hanyalah sekolah yang dikelola dengan kinerja dibawah standar. Kepala sekolah menjadi kunci utama dan tokoh sentral untuk mewujudkan perbaikan kinerja manajemen sekolah dan peningkatan kualitas pendidikan di Indonesia. Hal ini seiring dengan diberikannya wewenang yang lebih besar kepada sekolah untuk mengelola rumah tangganya sendiri. Sekolah menjadi lembaga otonom yang penyelenggaraannya tetap berada pada koridor Sistem Pendidikan Nasional (sisdiknas). Supervisi adalah usaha menstimulasi pertumbuhan dan perkembangan profesional para guru, seleksi dan revisi tujuan-tujuan pendidikan, bahan pengajaran, metode-metode mengajar, dan evaluasi pengajaran, sehingga memunculkan kreativitas dan inovasi. Gaya kepemimpinan kepala sekolah seperti apakah yang dapat menumbuhsuburkan kreativitas sekaligus dapat mendorong terhadap peningkatan kompetensi dan kinerja guru. Dalam teori kepemimpinan setidaknya kita mengenal dua gaya kepemimpinan yaitu kepemimpinan yang berorientasi pada tugas dan kepemimpinan yang berorientasi pada manusia. Dalam rangka meningkatkan kompetensi guru, seorang kepala sekolah dapat menerapkan kedua gaya kepemimpinan tersebut secara tepat dan fleksibel, disesuaikan dengan kondisi dan kebutuhan yang ada

Adanya pengaruh secara bersamasama kompetensi manajerial dan supervisi kepala sekolah dalam meningkatkan kinerja guru. Kinerja ini dijabarkan dalam 3 yaitu guru sebagai perencana, pelaksana dan evaluasi pembelajaran. Untuk melihat alur pikir yang digunakan dalam penelitian ini, pengaruh kompetensi manajerial dan supervisi kepala sekolah terhadap kinerja dapat dilihat pada gambar di bawah ini: 


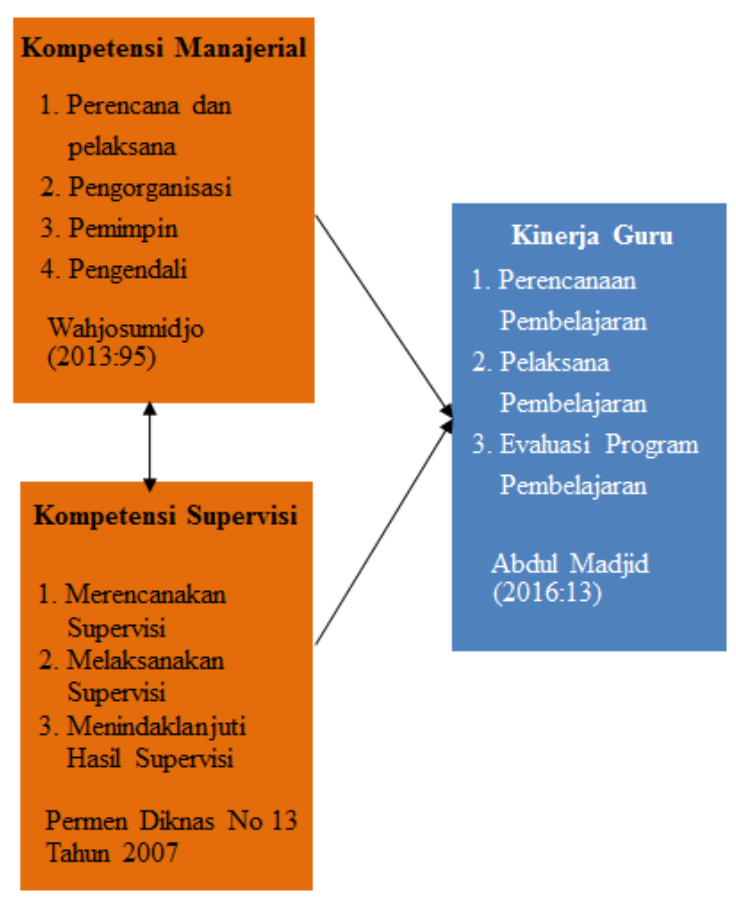

\section{Hipotesis Penelitian}

Bertitik tolak dari pertanyaan penelitian dan asumsi penelitian tersebut, selanjutnya ditetapkan hipotesis yang merupakan jawaban sementara terhadap masalah penelitian, yang kebenarannya harus dibuktikan atau diuji secara empiris, yaitu sebagai berikut :

1. Adanya signifikansi dari kompetensi manajerial kepala sekolah SMPN di Kecamatan Banjaran Kabupaten Majalengka.

2. Adanya signifikansi dari kompetensi supervisi kepala sekolah SMPN di Kecamatan Banjaran Kabupaten Majalengka.

3. Adanya signifikansi kinerja guru SMPN di Kecamatan Banjaran Kabupaten Majalengka.

4. Terdapat pengaruh yang positif dan signifikan kompetensi manajerial kepala sekolah terhadap kinerja guru SMPN di Kecamatan Banjaran Kabupaten Majalengka.

5. Terdapat pengaruh yang positif dan signifikan kompetensi supervisi kepala sekolah terhadap kinerja guru SMPN di Kecamatan Banjaran Kabupaten Majalengka.

6. Terdapat pengaruh yang positif dan signifikan kompetensi manajerial dan supervisi kepala sekolah terhadap kinerja guru SMPN di Kecamatan Banjaran Kabupaten Majalengka.

\section{METODE PENELITIAN}

Sebagaimana telah disebutkan dalam latar belakang, inti kajian dalam penelitian ini adalah pengaruh kompetensi manajerial dan supervisi kepala sekolah dalam meningkatkan kinerja guru SMPN Banjaran di Kecamatan Banjaran Kabupaten Majalengka. Tempat penelitian dilakukan di tiga Sekolah Menengah Pertama Negeri, yaitu SMPN 1 Banjaran, SMPN 2 Banjaran dan SMPN 3 Banjaran Kabupaten Majalengka. Alasan memilih ketiga sekolah tersebut karena penulis menjadi guru di salah satu dari ketiga sekolah tersebut dan jarak penulis ke sekolah tidak terlalu jauh sehingga memudahkan untuk melakukan proses penelitian. Penelitian didasarkan atas pertimbangan objektif sesuai dengan tujuan penelitian serta didasarkan atas kemudahan memperoleh data, dan hasil penelitiannya diharapkan dapat memberi masukan kepada pengambil kebijakan di daerah dan sekolah.

Penelitian pada dasarnya untuk menunjukkan kebenaran dan pemecahan masalah atas apa yang diteliti dan untuk mencapai tujuan tersebut dilakukan suatu metode yang tepat dan relevan. Sugiyono (2014:5) mendefinisikan metode penelitian adalah: "Cara ilmiah untuk mendapatkan data yang valid dengan tujuan dapat ditemukan, dikembangkan, dan dibuktikan, suatu pengetahuan tertentu sehingga pada gilirannya dapat digunakan untuk memahami, memecahkan, dan mengantisipasi masalah".

Metode penelitian perlu ditentukan oleh penulis untuk menentukan cara atau taktik yang tepat sebagai langkah-langkah yang harus ditempuh oleh penulis dalam memecahkan suatu permasalahan untuk mencapai tujuan tertentu yang hendak dicapai. Dengan metode penelitian, penulis bermaksud mengumpulkan data historis dan mengamati secara seksama mengenai aspekaspek tertentu berkaitan erat dengan masalah yang diteliti sehingga akan dipeoleh data-data yang menunjang penyusuanan laporan penulis. Dalam penelitian ini metode penelitian yang digunakan penulis dalam penelitian ini adalah metode studi empiris, 
yaitu penelitian terhadap fakta empiris yang diperoleh berdasarkan observasi dan pengalaman.

Menurut Sugiyono (2014:2) yang dimaksud dengan studi empiris adalah: "studi empiris berarti cara-cara yang dilakukan itu dapat diamati oleh indera manusia, sehingga orang lain dapat mengamati dan mengetahui cara-cara yang digunakan". Dalam melakukan penelitian ini, penulis menggunakan metode deskriptif dan verifikatif, karena adanya variabel-variabel yang akan ditelaah hubungannya, serta tujuan untuk menyajikan gambaran secara terstuktur, faktual, dan akurat mengenai fakta serta hubungan antar variabel yang diteliti, yaitu pengaruh kompetensi manajerial dan supervisi kepala sekolah dengan kinerja guru. Pengertian metode deskriptif menurut Sugiyono (201 3:53), yaitu: "Rumusan masalah yang berkenaan dengan pertanyaan terhadap keberadaan variabel mandiri, baik hanya pada satu variabel atau lebih (variabel mandiri adalah variabel yang berdiri sendiri, bukan variabel independen, karena variabel independen selalu dipasangkan dengan variabel dependen)."

Tujuan dari penelitian deskriptif adalah untuk mengetahui dan menganalisis pengaruh kompetensi manajerial dan supervisi kepala sekolah dalam meningkatkan kinerja guru. Metode deskriptif digunakan untuk mendeskripsikan atau menguraikan permasalahan yang berkaitan dengan pertanyaan terhadap variabel mandiri yaitu mendeskripsikan pengaruh kompetensi manajerial dan supervisi kepala sekolah dan pembuktian yang berguna untuk mencari kebenaran dari hipotesis yang diajukan. Selain itu juga untuk mengetahui pengaruh kompetensi manajerial dan supervisi kepala sekolah dalam meningkatkan kinerja guru. Berdasarkan metode yang telah diuraikan di atas, penulis bermaksud mengumpulkan data historis dan mengamati secara seksama mengenai aspek-aspek tertentu yang berkaitan dengan masalah yang diteliti sehingga akan diperoleh data-data yang menunjang penyusunan laporan penelitian. Data yang diperoleh tersebut kemudian diproses, dianalisis lebih lanjut dasar-dasar teori yang telah dipelajari sehingga memperoleh gambaran mengenai objek tersebut dan dapat ditarik kesimpulan mengenai masalah yang diteliti.

Metode verifikatif yaitu memeriksa benar tidaknya apabila dijelaskan untuk menguji suatu cara dengan atau tanpa perbaikan yang telah dilaksanakan di tempat lain dengan mengatasi masalah yang serupa dengan kehidupan. Verifikatif berarti menguji teori dengan pengujian suatu hipotesis apakah diterima atau ditolak. Menurut Sugiyono (2014:55), analisis verifikatif yaitu metode penelitian yang bertujuan untuk mengetahui hubungan antar dua variabel atau lebih. Metode ini digunakan untuk menguji kebenaran dari suatu hipotesis. Metode analisis yang digunakan adalah model regresi linier berganda. Menurut Sugiyono (2014:277) bahwa: "Analisis regresi linier berganda bermaksud meramalkan bagaimana keadaan (naik turunnya) variabel dependen (kriterium), bila dua atau lebih variabel independen sebagai faktor prediator dimanipulasi (dinaik turunkan nilainya).

\section{HASIL PENELITIAN DAN PEMBAHASAN}

Analisis regresi linear berganda hanya ditujukan pada pengukuran butirbutir pertanyaan yang valid dan reliabel, sehingga butir-butir pertanyaan yang tidak valid meskipun reliabel tidak dimasukkan dalam pengolahan data.

1) Uji Keterandalan Model (Uji F)

Uji keterandalan model yang lebih populer disebut sebagai uji $F$, ada juga yang menyebutnya uji simultan model merupakan tahap awal mengindentifikasi model regresi yang diestimasi layak (andal) atau tidak. Layak di sini yang dimaksud adalah model yang diestimasi apakah layak digunakan untuk menjelaskan pengaruh variabelvariabel independen terhadap variabel dependen. Ukuran dikatakan model regresi layak digunakan adalah melihat nilai sig. $\mathrm{F}$ hitung pada tabel ANOVA. Apabila nilai sig. F hitung lebih kecil dari kesalahan (alpha) 0,05 maka dapat dikatakan model regresi yang diestimasi layak, sedangkan apabila nilai sig. F hitung lebih besar tingkat kesalahan maka dapat dikatakan model regresi tidak layak. Sesuai pengolahan data melalui SPSS 21.0 pada tabel ANOVA di bawah ini, $F$ hitung 
sebesar 72,694 dengan sig. 0,000. Nilai sig. lebih kecil dari 0,05 maka model regresi yang diperoleh nantinya bisa digunakan untuk menjelaskan pengaruh kompetensi manajerial dan supervisi kepala sekolah terhadap kinerja guru.

Tabel 1 ANOVA

\begin{tabular}{|c|c|c|c|c|c|c|}
\hline \multicolumn{7}{|c|}{ ANOVIA" } \\
\hline \multicolumn{2}{|c|}{ Mosal } & $\begin{array}{l}\text { Sumb of } \\
\text { Sauress }\end{array}$ & dif & Wan $5 q$ quare & $\mp$ & $\$ g$ \\
\hline \multirow[t]{3}{*}{1} & Regassion & 4870.212 & 2 & 2435.100 & 72654 & $0: 0^{1}$ \\
\hline & Revidual & 1875,869 & 56 & 33458 & & \\
\hline & Total & $6746: 102$ & 68 & & & \\
\hline \multicolumn{7}{|c|}{ a Depenaentvaraute Krevia_Gury } \\
\hline \multicolumn{7}{|c|}{ 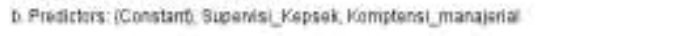 } \\
\hline \multicolumn{7}{|c|}{ Sumber : data penelitian diolah, 2020} \\
\hline
\end{tabular}

\section{2) Uji Koefisien Regresi (Uji t)}

Uji $t$ dalam regresi liniear berganda dimaksudkan untuk menguji apakah parameter, dalam hal ini adalah koefisien regresi dan konstanta yang diduga untuk mengestimasi model regresi liniear berganda sudah merupakan parameter yang tepat atau belum. Tepat yang dimaksud adalah parameter tersebut bisa menjelaskan perilaku variabel independen dalam mempengaruhi variabel dependen. Parameter yang diestimasi adalah intersep (konstanta) dan slope (koefisien persamaan linier). Uji $t$ melalui SPSS dapat dengan mudah ditarik kesimpulannya. Apabila nilai sig. $\mathrm{t}$ hitung dalam tabel Cofficients lebih kecil dari tingkat kesalahan (alpha) 0,05 maka dapat dikatakan bahwa variabel independen berpengaruh signifikan terhadap variabel dependen, sedangkan nilai sig. $t$ hitung lebih besar dari tingkat kesalahan 0,05 maka dapat dikatakan bahwa variabel independen tidak berpengaruh signifikan terhadap variabel dependen. Sesuai pengolahan data melalui SPPS pada tabel Coefficients di bawah ini, nilai sig. $t$ hitung dari variabel kompetensi manajerial (x1) sebesar 5,083 dan variabel supervisi kepala sekolah (x2) sebesar 0,654. Sesuai nilai sig. t hitung ketiga variabel independen tersebut, variabel kompetensi manajerial (x1) dan supervisi kepala sekolah (x2) mempunyai nilai sig.t hitung lebih kecil dari 0,05 sehingga kedua variabel tersebut berpengaruh signifikan terhadap kinerja guru (Y).
Tabel 2 Coefficients - Uji t

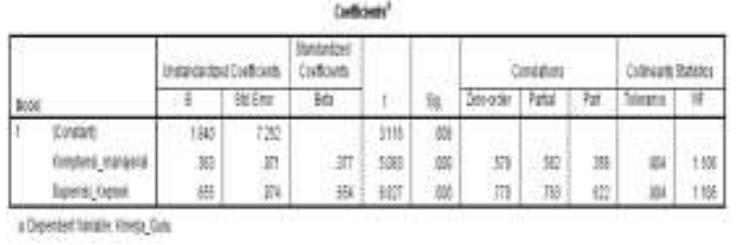

Sumber : data penelitian diolah, 2020

\section{3) Koefisien Determinasi}

Koefisien determinasi menjelaskan variasi pengaruh variabel-variabel independen terhadap variabel dependen, atau dapat dikatakan proporsi pengaruh seluruh variabel independen terhadap variabel dependen. Nilai koefisien tersebut dapat diukur oleh nilai R-Square atau Adjusted R-Square. Peneliti akan memakai nilai R-Square. Sesuai pengolahan data melalui SPSS 21.0 pada tabel Model Summary di bawah ini, nilai $\mathrm{R}$ square (koefisien determinasi) sebesar 0,722 artinya variabel kompetensi manajerial dan supervisi kepala sekolah berpengaruh bersama-sama terhadap kinerja guru sebesar 72,2\%. Proporsi sisanya dipengaruhi variabel- variabel lain yang tidak diteliti. Hal tersebut sesuai dengan kajian teori yang dibahas sebelumnya bahwa banyak faktor yang bisa mempengaruhi kinerja guru selain kompetensi manajerial dan supervisi kepala sekolah.

Tabel 3 Model Summary

\begin{tabular}{|c|c|c|c|c|c|}
\hline \multicolumn{6}{|c|}{ Model Summary" } \\
\hline Model & $R$ & R Square & $\begin{array}{l}\text { Aglusted R } \\
\text { Square }\end{array}$ & $\begin{array}{l}\text { SHI Error of } \\
\text { the Esimate }\end{array}$ & $\begin{array}{l}\text { Durbin- } \\
\text { Watson }\end{array}$ \\
\hline 1 & $850^{3}$ & .722 & .712 & 5.78775 & 1.840 \\
\hline
\end{tabular}

Sumber : data penelitian diolah, 2020

\section{4) Interpretasi Model}

Setelah diuji pemenuhan persyaratan kualitas data yang akan diolah dalam regresi liniear berganda melalui uji asumsi klasik, estimasi model regresi liniear berganda dijalankan serta kelayakan model regresi tersebut, maka tahap terakhir adalah menginterpretasi koefisien regresi yang termuat dalam model regresi linier berganda. Interpretasi koefisien regresi meliputi dua hal, tanda dan besaran. Tanda menunjukkan arah hubungan. Tanda dapat mempunyai nilai positif atau negatif. Positif 
menunjukkan pengaruh yang searah antara variabel independen terhadap variabel dependen, sedangkan negatif menunjukkan pengaruh yang berlawanan arah antara variabel independen terhadap variabel dependen. Searah yang dimaksud adalah apabila variabel independen mengalami kenaikan, peningkatan atau bertambah maka variabel depdenen akan mengalami hal yang sama kenaikan, peningkatan atau bertambah. Apabila variabel independen mengalami penurunan atau pengurangan maka akan berdampak kepada variabel dependen yang akan mengalami penurunan atau pengurangan.

Berlawanan yang dimaksud adalah apabila variabel dependen mengalami kenaikan, peningkatan atau bertambah maka variabel dependen akan mengalami hal yang sebaliknya yaitu penurunan atau pengurangan. Jika variabel independen mengalami penurunan atau pengurangan maka variabel dependen akan mengalami kenaikan, peningkatan atau bertambah. Sesuai pengolahan data melalui SPSS 20 pada tabel Coefficient di bawah ini, persamaan model regresi bisa diketahui adalah

$$
\mathrm{Y}=1,840+0,363 \mathrm{x}_{1}+0,655 \mathrm{x}_{2}
$$

Tabel 4.

Coefficients - Intepretasi Model

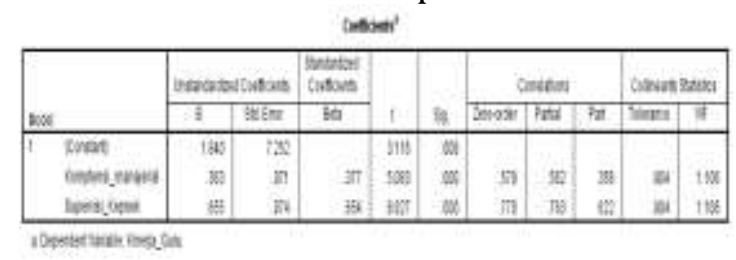

Sumber : data penelitian diolah, 2020

Koefisien regresi variabel kompetensi manajerial (x1) mempunyai nilai positif $(0,398)$ artinya pada saat skor variabel kompetensi manajerial (x1) naik maka skor kinerja guru (y) juga akan mengalami kenaikan. Begitu pula pada saat skor variabel kompetensi manajerial (x1) turun maka skor kinerja guru (y) juga turun. Kenaikan skor variabel kompetensi manajerial (x1) sebesar 1 poin akan berakibat pada peningkatan skor variabel kinerja guru (y) sebesar 0,363 poin dan sebaliknya. Koefisien regresi variabel kompetensi manajerial (x1) mempunyai nilai positif $(0,363)$ artinya pada saat skor variabel kompetensi manajerial (x1) naik maka skor kinerja guru (y) juga akan mengalami kenaikan. Begitu pula pada saat skor variabel kompetensi manajerial (x1) turun maka skor kinerja guru (y) juga turun. Kenaikan skor variabel kompetensi manajerial (x1) sebesar 1 poin akan berakibat pada peningkatan skor variabel kinerja guru (y) sebesar 0,363 poin dan sebaliknya.

Koefisien regresi variabel supervisi kepala sekolah (2 mempunyai nilai positif $(0,655)$ artinya pada saat skor variabel supervisi kepala sekolah (x2) naik maka skor kinerja guru (y) juga akan mengalami kenaikan. Begitu pula pada saat skor variabel supervisi kepala sekolah (x2) turun maka skor kinerja guru (y) juga turun. Kenaikan skor variabel supervisi kepala sekolah (x2) sebesar 1 poin akan berakibat pada peningkatan skor variabel kinerja guru $(y)$ sebesar 0,655 poin dan sebaliknya. Koefisien regresi variabel supervisi kepala sekolah (x2) mempunyai nilai positif $(0,655)$ artinya pada saat skor variabel supervisi kepala sekolah (x2) naik maka skor kinerja guru (y) juga akan mengalami kenaikan. Begitu pula pada saat skor variabel supervisi kepala sekolah (x2) turun maka skor kinerja guru (y) juga turun. Kenaikan skor variabel supervisi kepala sekolah (x2) sebesar 1 poin akan berakibat pada peningkatan skor variabel kinerja guru (y) sebesar 0,655 poin dan sebaliknya.

\section{5) Pembahasan Uji Hipotesis}

Penelitian ini mempunyai beberapa hipotesis penelitian yang ingin diuji adalah kompetensi manajerial berpengaruh signifikan terhadap kinerja guru (H1), supervisi kepala sekolah berpengaruh signifikan terhadap kinerja guru (H2), kompetensi manajerial dan supervisi kepala sekolah berpengaruh signifikan secara bersama-sama terhadap kinerja guru (H3). Hasil pengujian hipotesis ke-1 (H1) melalui uji t menunjukkan bahwa nilai sig. t hitung variabel kompetensi manajerial sebesar 0,000 yang lebih besar dari 0,05. Kondisi tersebut dapat disimpulkan bahwa hipotesis ke-1 (H1) diterima atau dengan kata lain kompetensi manajerial di SMP Negeri se Kecamatan Banjaran berpengaruh signifikan terhadap kinerja guru.

Hasil pengujian hipotesis ke-2 (H2) melalui uji $t$ menunjukkan bahwa nilai sig. $t$ 
hitung variabel supervisi kepala sekolah sebesar 0,000 yang lebih kecil dari 0,05. Kondisi tersebut dapat disimpulkan bahwa hipotesis ke-2 (H2) diterima atau dengan kata lain supervisi kepala sekolah di SMP Negeri se Kecamatan Banjaran berpengaruh signifikan terhadap kinerja guru. Hasil pengujian hipotesis ke-4 (H4) melalui uji $\mathrm{F}$ menunjukkan bahwa nilai sig $F$. hitung sebesar 0,000 yang lebih kecil dari 0,05. Kondisi tersebut dapat disimpulkan bahwa hipotesis ke-4 (H4) diterima atau dengan kata lain kompetensi manajerial dan supervisi kepala sekolah di SMP Negeri se Kecamatan Banjaran berpengaruh signifikan secara bersama-sama terhadap kinerja guru. Apabila ditinjau dari nilai R-square model regresi penelitian ini, proporsi pengaruh kompetensi manajerial dan supervisi kepala sekolah secara bersama-sama terhadap kinerja guru sebesar 72,2\%. Proporsi pengaruh variabel-variabel lainnya yang tidak diteliti sebesar 27,8\%.

Hasil uji hipotesis diperoleh bahwa kompetensi manajerial dan supervisi kepala sekolah berpengaruh signifikan secara bersama-sama terhadap kinerja guru. Secara parsial kompetensi manajerial kepala sekolah secara statistic berpengaruh signifikan terhadap kinerja guru. Hasil penelitian ini membuktikan secara empiris bahwa kemampuan manajerial yang dimiliki kepala sekolah dapat memberikan pengaruh terhadap guru untuk meningkatkan kualitasnya sebagai tenaga pendidik, sebagaimana pendapat Mulyasa (2006) bahwasannya "seorang kepala sekolah harus memiliki strategi yang tepat untuk memberdayakan tenaga kependidikan melalui kerja sama atau kooperatif, memberi kesempatan kepada para tenaga kependidikan untuk meningkatkan profesinya, dan mendorong keterlibatan seluruh tenaga kependidikan dalam berbagai kegiatan yang menunjang program sekolah". Program penunjang sekolah terdiri dari berbagai kegiatan yang dapat guru lakukan sebagai untuk meningkatkan profesinya dan meningkatkan kinerjanya secara maksimal.

Kepala sekolah sebagai salah satu pengelola satuan pendidikan juga disebut sebagai administrator, dan disebut juga sebagai manajer pendidikan. Maju mundurnya kinerja sebuah organisasi ditentukan oleh seorang manajer. Kepala sekolah sebagai manajer merupakan pemegang kunci maju mundurnya sekolah. Peran kepala sekolah sebagai manager harus memiliki strategi-strategi yang efektif dan efisien untuk mengimplementasikan berbagai kebijakan dan keputusan yang telah ditetapkan.

Kemampuan manajerial kepala sekolah merupakan kemampuan kepala sekolah dalam melakukan proses manajemen meliputi merencanakan, mengorganisasikan, memimpin, dan mengendalikan usaha-usaha anggota organisasi serta pelaksanaan keterampilan pendayagunaan seluruh sumberdaya organisasi dalam rangka mencapai tujuan yang telah ditetapkan di suatu instansi sekolah. Hasil penelitian ini menunjukkan bahwa kemampuan manajerial kepala sekolah menurut persepsi guru secara keseluruhan baik. Walaupun kemampuan manajerial menurut persepsi guru sudah baik, namun kepala sekolah harus meningkatkan kemampuan manajerialnya terutama pada aspek memimpin karena dari hasil pengukuran variabel kemampuan manajerial kepala sekolah, aspek terendah adalah Kepala sekolah dapat menentukan sasaran sekolah secara realistis dengan menetukan kreteria yang dapat di ukur dengan nilai rata-rata sebesar 2.98 dan indicator Kepala sekolah dapat menentukan langkah-langkah strategis untuk mencapai misi dan tujuan sekolah dengan nilai ratarata sebesar 3,08 Hal itu menandakan ada beberapa guru yang menilai aspek Kepala sekolah dapat menentukan sasaran sekolah secara realistis dengan menetukan kreteria yang dapat di ukur dan Kepala sekolah dapat menentukan langkah-langkah strategis untuk mencapai misi dan tujuan sekolah yang dilakukan kepala sekolah masih lebih rendah dari aspek yang lainnya. Kemampuan manajerial sebagai salah satu faktor yang berpengaruh terhadap kinerja guru, meski variabel kemampuan manajerial kepala sekolah terhadap kinerja guru telah dikatakan sangat baik namun kepala sekolah dan guru harus tetap meningkatkan kualitas pendidikan melalui kualitas kepala sekolah dan kualitas guru.

Supervisi Kepala Sekolah secara parsial berpengaruh signifikan terhadap kinerja. 
Hasil penelitian ini menunjukkan bahwa kegiatan supervisi yang telah dilaksanakan oleh kepala sekolah terbukti memiliki pengaruh yang positif terhadap kinerja guru. Menurut Purwanto (2000) dalam Doni dan Risma (2014: 83) supervisi pendidikan merupakan suatu aktifitas pembinaan yang direncanakan untuk membantu para guru dan pegawai sekolah lainnya dalam melakukan pekerjaan secara efektif. Kemudian menurut Manulang (2005) dalam Doni dan Risma (2014: 83) menyatakan bahwa "supervisi merupakan suatu proses untuk menerapkan pekerjaan apa yang sudah dilaksanakan, menilainya, dan bila perlu mengoreksinya dengan maksud supaya pelaksanaan sesuai dengan rencana semula".

Misi utama supervisi pendidikan adalah memberi pelayanan kepada guru agar mampu mengembangkan mutu pembelajaran, memfasilitasi guru agar dapat mengajar dengan efektif sehingga terjadi peningkatan mutu pembelajaran dan peningkatan kinerja guru. Kemudian menurut Donni dan Risma (2014:84), kegiatan supervisi digunakan untuk memajukan pembelajaran melalui pertumbuhan kemampuan guru-gurunya. Supervisi mendorong guru menjadi lebih berdaya, dan situasi belajar mengajar menjadi lebih baik, pengajaran menjadi efektif, guru menjadi lebih puas dalam melaksanakan pekerjaannya terdapat peningkatan dalam kinerjanya.

Fungsi kepala sekolah merupakan salah satu faktor penting dalam menumbuhkan jabatan guru melalui supervisi yang dilakukan di sekolah. Dengan adanya koordinasi kepala sekolah, guru dapat berkembang serta meningkatkan prestasi kerja menurut bidangnya masing-masing, selain itu kepala sekolah sebagai pemimpin pendidikan di sekolah harus selalu mengawasi, dan mengontrol seluruh kegiatan-kegiatan guru dan bawahan lainnya di sekolah, sehingga akan tercapai tujuan yang diinginkan. Berhasil atau tidaknya seorang guru sangat dipengaruhi oleh adanya supervisi dari kepala sekolah. Dengan demikian kepala sekolah sebagai pemimpin di sekolah dituntut agar memiliki kemampuan dan keterampilan tentang supervisi.
Kepala sekolah harus bertanggung jawab terhadap kemajuan guru-guru. Ia harus sanggup memberikan bantuan kepada guru-guru agar para guru dapat mengerti dan dapat memberikan penilaian terhadap kecenderungan-kecenderungan keinginan yang ada dalam masyarakat setempat, sehingga tujuan pendidikan dapat tercapai. Dalam meningkatkan proses belajar mengajar guru harus saling memberi dan menerima informasi dengan Kepala Sekolah, sehingga seluruh tugas-tugasnya akan berjalan selain itu diperlukan bentuk hubungan dan kerja sama berdasarkan kedudukan sejajar, Kepala Sekolah, komite sekolah dan semua warga sekolah perlu menjunjung tinggi hubungan kerja sama demi mewujudkan tujuan pendidikan, ini berarti bahwa bahwa kepala sekolah maupun komite sekolah dalam menjalankan tugasnya tidak saling mendominasi satu sama lain, tidak saling melanggar wewenang masing-masing tapi saling bahu-membahu berdasarkan aturan yang ditetapkan.

Hasil penelitian ini menunjukkan bahwa supervisi kepala sekolah menurut persepsi guru secara keseluruhan baik. Walaupun supervisi kepala sekolah menurut persepsi guru sudah baik, namun kepala sekolah harus meningkatkan kegiatan supervisinya terutama pada aspek Kepala sekolah mengamati guru dalam proses pembelajaran untuk memperoleh data kemampuan maupun kelemahan guru untuk kepentingan pembelajaran dan Kepala sekolah memberikan peringatan kepada guru yang berperilaku buruk yang merupakan aspek terendah dengan nilai rata-rata sebesar 3,07 dan 3,08. Hal itu menandakan ada beberapa guru yang menilai aspek Kepala sekolah mengamati guru dalam proses pembelajaran untuk memperoleh data kemampuan maupun kelemahan guru untuk kepentingan pembelajaran dan Kepala sekolah memberikan peringatan kepada guru yang berperilaku buruk yang dilakukan kepala sekolah masih lebih rendah dari aspek yang lainnya.

\section{PENUTUP}

1. Kompetensi manajerial kepala sekolah pada umumnya berada pada kategori cukup baik. Namun demikian terdapat dua indicator yang perlu ditingkatkan 
yaitu Kepala sekolah dapat menentukan sasaran sekolah secara realistis dengan menetukan kreteria yang dapat di ukur dan Kepala sekolah dapat menentukan langkah-langkah strategis untuk mencapai misi dan tujuan sekolah yang merupakan indicator terendah bila dibandingkan dengan indicator lainnya.

2. Kegiatan supervisi kepala sekolah pada umumnya berada pada kategor cukup baik. Namun demikian masih ada dua indicator yang terendah di antaranya Kepala sekolah mengamati guru dalam proses pembelajaran untuk memperoleh data kemampuan maupun kelemahan guru untuk kepentingan pembelajaran dan Kepala sekolah memberikan peringatan kepada guru yang berperilaku buruk.

3. Kinerja guru pada umumnya berada pada kategori baik. Namun demikian ada dua indicator yang perlu ditingkatkan kinerjanya di antaranya Guru membuat program tahunan dan semester dan Guru memberi siswa tugas pekerjaan rumah.

4. Kompetensi manajerial yang didasarkan dari hasil uji hipotesis secara statistic menunjukkan berpengaruh positif dan signifikan terhadap kinerja guru.

5. Kegiatan supervisi kepala sekolah yang didasarkan dari hasil uji hipotesis secara statistic menunjukkan berpengaruh positif dan signifikan terhadap kinerja guru.

6. Kompetensi manajerial dan supervisi kepala sekolah yang didasarkan dari hasil uji hipotesis secara statistic secara simultan menunjukkan berpengaruh positif dan signifikan terhadap kinerja guru.

Berdasarkan kesimpulan di atas, maka saran dalam penelitian ini sebagai berikut :

1. Kepada Dinas Pendidikan Kabupaten Majalengka hendaknya: a) memberikan pembinaan lebih intensif kepada kepala sekolah untuk meningkatkan efektivitas sekolah, b) pelatihan untuk pengembangan kemampuan mengelola sekolah bagi kepala sekolah, dan c) meningkatkan peran pengawas / penilik sekolah dalam melakukan supervisi manajerial terhadap kepala sekolah.
2. Kepada pihak kepala sekolah untuk kedepannya melakukan peningkatanpeningkatan atau inovasi dalam melaksanakan supervisi. kemudianhendaknya para guru lebih terbuka ketika kegiatan supervisi dilaksanakan dan meneis anggapan bahwa kegiatan supervisi adalah kegiatan untuk mencari kesalahan melainkan untuk membantu guru dalam mengatasi masalah yang dihadapi.

3. Kepada kepala sekolah hendaknya melakukan supervisi kelas secara berkala dan teratur dengan pendekatan personal.

4. Kepala sekolah hendaknya meningkatkan kualitas kepemimpinannya untuk memberikan pengaruh yang positif kepada bawahannya, sehingga seluruh warga sekolah merasa nyaman berada di lingkungan sekolah

5. Kepada Kepala Sekolah hendaknya: a) mengembangkan kompetensi secara terus menerus untuk meningkatkan kemampuan manajerialnya, meningkatkan kerja sama dengan intansi terkait dalam rangka mengembangkan dirinya, dan c) melakukan studi lanjut agar kompetensinya meningkat.

6. Kepada guru hendaknya meningkatkan kinerjanya bukan hanya karena adanya pengawasan dari kepala sekolah melainkan dengan keinginan dari dalam diri sendiri.

\section{DAFTAR PUSTAKA}

Arikunto, Suharsimi. 2005. Manajemen Penelitian. Jakarta; Renika Cipta.

Arikunto, Suharsimi. 2006. Prosedur Penelitian Suatu Pendekatan Praktik. Jakarta; Rineka Cipta.

Arikunto, Suharsimi. 2002. Metodologi Penelitian. Jakarta; Penerbit PT. Rineka Cipta

Arsyad, Azhar. 2003. Pokok-Pokok Manajemen. Yogyakarta: Pustaka Pelajar.

As ad. 1995. Seri Ilmu Sumber Daya Manusia: Psikologi Industri. Jakarta; Gramedia Pustaka Utama. 
Atkinson, R.L., dkk. 2000. Hilgards Introduction to Psychology. ( 13 th ed). Editor : Smith, Carolyn D. Harcourt College Publishers.

Bafadal, Ibrahim. 2003. Peningkatan Profesional Guru SD. Jakarta, Bumi Aksara. Bernard, Ci.

Chandrani, Eka Nugrah Hilovar. 2003. Pengaruh Kepemimpinan Kepala Sekolah Dan Budaya. Jakarta; Persada

Hasibuan, Malayu. 2001. Manajemen Sumber Daya Manusia :Pengertian. Dasar, Pengertian, dan Masalah. Jakarta: PT. Cipta Rineka.

Jalal, Fasli dan Dedi Supriadi.2001. Reformasi Pendidikan dalam Konteks Otonomi Daerah. Jakarta: Depdiknas Bapenas Adicitakaryanusa.
Mamduh, M. Hanafi. 1997. Manajemen. Yogyakarta; UPP AMP YKPN.

Martinis Yamin. 2006. Profesionalisasi Guru dan Implementasi Kurikulum Berbasis Kompetensi. Jakarta; Penerbit Erlangga.

Martoyo. 2006. Prosedur Penelitian Suatu Pendekatan Praktek. Jakarta; Rineka Cipta.

Mulyasa, E. 2005. Menjadi Guru Profesional. . Bandung; PT. Remaja.

\section{BIOGRAFI PENULIS}

\begin{tabular}{||l|l|l||}
\hline & $\begin{array}{l}\text { Lelah, Mahasiswa Program Magister Ilmu Administrasi, Universitas } \\
\text { Majalengka, Jawa Barat, Indonesia. } \\
\text { email: lelah.76@ gmail.com }\end{array}$ \\
\hline \hline & & \\
\hline \hline & & \\
\hline
\end{tabular}

